\title{
PENGARUH KONSENTRASI SUKROSA DAN GLISERIN TERHADAP SABUN TRANSPARAN DAUN KETEPENG (Cassia alata)
}

\author{
Encik Eko Rifkowaty ${ }^{1}$, Dian Fitriarni ${ }^{1}$ \\ Jurusan TEKNOLOGI PENGELOLAAN HASIL PERTANIAN, Prodi TEKNOLOGI \\ PENGOLAHAN HASIL PERKEBUNAN, Politeknik Negeri Ketapang, Jalan Rangge Sentap \\ Kec.Delta Pawan Kel.Sukaharja Ketapang \\ Email: encik.rifkowaty@politap.ac.id
}

\begin{abstract}
Abstrak
Ketepeng cina dimanfaatkan secara tradisional dengan cara digosokkan atau ditempelkan pada kulit yang sakit untuk mengobati kurap dan penyebab gatal. Pembuatan sabun transparan dengan penambahan ekstrak daun ketepeng merupakan salah satu upaya untuk meningkatkan efisiensi penggunaan daun ketepeng dalam pemanfaatannya sebagai obat-obatan. Penelitian ini bertujuan untuk mengetahui formulasi terbaik dari sabun yang dihasilkan. Penelitian ini terdiri dari beberapa tahap. Tahap pertama yaitu pembuatan sabun transparan berbahan baku minyak kelapa murni (Virgin Coconut Oil) dengan berbagai formulasi sukrosa (7,5 gr, 9,5 gr dan 11,5 gr) dan gliserin (6,5 gr, 8,5 gr, dan 10,5 gr). Analisa yang dilakukan meliputi kadar air, pH, angka penyabunan, stabilitas busa, alkali bebas, dan zona hambat. Perlakuan terbaik ditentukan dengan menggunakan metode DeGarmo. Tahap kedua, perlakuan terbaik berdasarkan uji DeGarmo ditambahkan berbagai variasi parfum dengan konsentrasi 3,5\% antara lain lemon, daun jambu, kenanga, dan melati dengan parameter organoleptik yang diamati aroma, busa, penampakan secara keseluruhan, dan uji iritasi. Berdasarkan hasil pengamatan diketahui bahwa perlakuan terbaik berdasarkan uji DeGarmo adalah sabun transparan dengan konsentrasi sukrosa 7,5 gram dan gliserin 6,5 gram, sedangkan variasi parfum yang disukai yaitu sabun transparan penambahan parfum daun jambu.
\end{abstract}

Kata kunci : Ekstrak daun ketepeng, Parfum, Sabun transparan, Sukrosa dan gliserin, VCO

\section{PENDAHULUAN}

Pembuatan sabun transparan dengan penambahan bahan alami telah dilakukan antara lain penambahan daun kemangi (Idrus, dkk., 2013), penambahan lidah buaya (Aloe vera) (Hambali, dkk., 2015), dan ekstrak lengkuas (Alpinia galanga) (Hernani, 2010).

Salah satu bahan alam yang memiliki potensi untuk diteliti adalah ketepeng cina. Ketepeng cina dimanfaatkan secara tradisional sebagai sebagai antiparasit, kurap, kudis, panu, dan eksem (Kusnardi, dkk. 2007). Virgin Coconot Oil (VCO) merupakan salah satu bahan baku pembuatan sabun. VCO memiliki efek penyabunan yang baik karena memiliki sifat mudah tersaponifikasi (Widyasanti, dkk., 2017). Sedangkan sukrosa dan gliserin merupakan bahan tambahan yang mempengaruhi tingkat pembusaan dan transparansi sabun. Menurut Priani dan Lukmayani (2010) Sukrosa bersifat humektan yang dapat membantu pembusaan sabun. Menurut Febriyenti, dkk., (2014) gliserin berfungsi sebagai emollient atau pelembab pada kulit, serta komponen pembentuk transparan pada sabun bersamaan dengan sukrosa dan alkohol.

Daun ketepeng memiliki bau khas yang kurang menarik indra penciuman. Salah satu upaya yang dapat dilakukan adalah dengan menambahkan parfum. Parfum merupakan bahan yang ditambahkan dalam suatu produk kosmetik dengan tujuan menutupi bau yang tidak enak dari bahan lain dan untuk memberikan wangi yang menyegarkan terhadap pemakainya (Utami, 2009). Penelitian tentang penambahan parfum pada sabun transparan telah dilakukan silvia (2008), penambahan parfum minyak nilam 3\%, Muchtaridi (2008) penambahan minyak akar wangi $1 \%$.

Hal inilah yang menjadi dasar dilakukannya penelitian pengaruh konsentrasi sukrosa dan gliserin terhadap sabun transparan daun ketepeng. Formulasi terbaik sabun transparan yang ditentukan berdasarkan uji DeGarmo, dilanjutkan dengan penambahan berbagai variasi parfum. 


\section{METODE}

Pembuatan ekstrak daun ketepeng dilakukan dengan menghancurkan daun ketepeng $100 \mathrm{~g}$ dengan menambahkan pelarut alkohol $70 \%$. Perbandingan bahan dan pelarut 1:10. Setelah itu dilakukan penyaringan, kemudian filtrat diuapkan menggunakan rotary evaporator (RV-10, IKA-WERKE, Germany) pada suhu $70^{\circ} \mathrm{C}$, kecepatan $80 \mathrm{rpm}$, dan waktu \pm 9 jam hingga didapatkan ekstrak kental.

Pembuatan sabun transparan dilakukan dengan memanaskan 50 gram minyak VCO pada suhu $70^{\circ} \mathrm{C}$ kemudian larutkan $\mathrm{NaOH}$ (Merck) sebanyak $5 \mathrm{~g}$ dalam $5 \mathrm{ml}$ air, aduk hingga larut, masukkan ke dalam minyak, kemudian ditambahkan etanol 7,5 g. Tambahkan sukrosa (gulaku) yang sudah dilarutkan dan gliserin (Brataco), aduk hingga terbentuk stok sabun, tambahkan $\mathrm{NaCl}$ (Merck) 0,2 g, asam sitrat 0,2 g, ekstrak ketepeng $2 \mathrm{~g}$, parfum 3,5\%, sampai semua campuran homogen. Tuangkan ke dalam cetakan dan diamkan sampai sabun mengeras. Sabun yang dihasilkan kemudian dilakukan uji kadar air (Sudarmadji, 1989), pH (Setyoningrum, 2010), angka penyabunan (Sudarmadji, 1989), stabilitas busa (Mumpuni dan Sasongko, 2017), alkali bebas (modifikasi Sukeksi, dkk., 2017), dan zona hambat (Juliansyah dan Paotonan, 2017). Perlakuan terbaik ditentukan mengggunakan uji DeGarmo (De Garmo, Sullivan, dan Canada, 1984).

Tahap kedua yaitu penambahan berbagai variasi parfum dengan parameter pengujian organoleptik aroma, busa, penerimaan keseluruhan menggunakan panelis semi terlatih berjumlah 25 orang dengan skala hedonik 1-9 (Setyaningsih, dkk., 2010), dan uji iritasi (Febriyenti, Sari, Nofita, 2014).

\section{PH}

Sabun ditimbang 1 gram dan dilarutkan dalam $10 \mathrm{ml}$ aquadest. $\mathrm{pH}$ meter dicelupkan ke dalam larutan. Derajat keasaman yang diproleh diamati, kemudian dicatat hasilnya.

\section{Jumlah alkali bebas}

Sabun transparan ditimbang 10 gram, kemudian dilarutkan dalam alkohol panas $50 \mathrm{ml}$, kemudian ditetesi indikator pp 2-3 tetes, direfluks \pm 30 menit, kemudian didinginkan, lalu dititrasi menggunakan $\mathrm{KOH} \quad 0,1 \%$ hingga muncul warna merah muda, catat volume titrasi dan hitung. alkali bebas $=\frac{V x B M x N}{W x 1000} \times 100 \%$

$$
\begin{aligned}
& \text { Keterangan: } \\
& \mathrm{V} \quad \text { = volume titrasi } \\
& \mathrm{BM} \quad=\text { berat molekul } \\
& \mathrm{W} \quad=\text { berat sampel }
\end{aligned}
$$

\section{Stabilitas busa}

Sebanyak 1 gram sampel dilarutkan dalam $9 \mathrm{~mL}$ air, dimasukkan ke dalam tabung reaksi, kemudian dikocok selama 30 detik. Busa yang terbentuk diukur tingginya. Sampel didiamkan selama 1 jam, kemudian tinggi busanya diukur kembali. Jika sampel yang diukur jumlahnya lebih dari satu, harus digunakan tabung-tabung reaksi yang dimensinya sama. Pengukuran dilakukan sebanyak 3 kali pengulangan.

Stabilitas Busa (\%) $=\frac{\text { Tinggi Akhir Busa }(\mathrm{mm})}{\text { Tinggi Awal Busa (mm) }} \times 100 \%$

\section{Uji Zona Hambat Bakteri}

Peremajaan mikroba uji

Isolate bakteri yang digunakan adalah Escherichia coli ATCC 25922. Media NA ditimbang sebanyak 5 gram kemudian dilarutkan dengan aquadest sebanyak $250 \mathrm{ml}$. Lakukan sterilisasi hingga suhu mencapai $121^{\circ} \mathrm{C}$ dan dipertahankan selama 15 menit, kemudian masukan media ke dalam masing-masing tabung reaksi untuk dijadikan NA miring. Setelah NA miring padat diambil dari biakkan bakteri Escherichia coli ATCC 25922 sebanyak satu ose kemudian diinokulasi pada media NA miring. Bakteri uji diinkubasi selama 24 jam pada suhu $37 \circ \mathrm{C}$, setelah itu dapat digunakan sebagai mikroba uji.

Pembuatan suspensi bakteri uji

Bakteri uji hasil peremajaan, kemudian disuspensikan dengan larutan $\mathrm{NaCl} 0,9 \%$ yang dimasukan ke dalam masing-masing tabung rekasi kemudian dicampurkan dengan media NA steril setelah itu dihomogenkan.

Pengujian zona hambat bakteri

Dibuat media NA padat ke dalam cawan petri, setelah memadat siapkan suspensi bakteri uji. Dicelupkan lidi berujung kapas pada suspensi bakteri uji lalu usapakan secara vertikal dan horizontal kepermukaan NA yang telah memadat sampai tertutup seluruh 
permukaannya, didiamkan hingga seluruh permukaan kering. Semetara itu dilelehkan tiap sample sabun transparan di atas hot plate. Direndam kertas cakram \pm 1 jam kedalam sample sabun yang telah dilelehkan, setelah itu kertas cakram dikeringkan. Setelah seluruh permukaan NA kering, kertas cakram yang telah direndam pada sabun transparan di letakan diatas permukaan NA tersebut dengan menggunakan pinset. Diinkubasi pada suhu 37。 C selama 24-48 jam. Cawan petri yang telah diinkubasi selama 24-48 jam kemudian diamati dan diukur diameter hambatannya.

\section{Uji Iritasi Kulit}

Uji iritasi dilakukan dengan mencuci tangan hingga pergelangan sampai sabun berbusa selama 3 hari berturut-turut. Pemeriksaan ini dilakukan terhadap lima orang panelis yang sama untuk masing-masing sabun. Diamati iritasi yang terjadi dengan memberikan penilaian (-) untuk tidak terjadi iritasi, (+) untuk iritasi ringan, $(++)$ untuk iritasi berat.

\section{HASIL DAN PEMBAHASAN}

Tabel 1 adalah analisa mutu sabun transparan dengan perlakuan sukrosa dan gliserin.

Tabel 1. Analisa Mutu Sabun Transparan

\begin{tabular}{|c|c|c|c|c|c|c|}
\hline $\begin{array}{l}\text { Perla } \\
\text { kuan }\end{array}$ & $\begin{array}{c}\text { Kada } \\
\mathbf{r} \\
\text { air } \\
(\%)\end{array}$ & pH & $\begin{array}{c}\text { Angk } \\
\text { a } \\
\text { peny } \\
\text { abun } \\
\text { an } \\
(\mathrm{Mg} / \\
\mathrm{NaO} \\
\mathrm{H})\end{array}$ & $\begin{array}{c}\text { Stabil } \\
\text { itas } \\
\text { busa } \\
(\%)\end{array}$ & $\begin{array}{c}\text { Alkal } \\
\text { i } \\
\text { bebas } \\
(\%)\end{array}$ & $\begin{array}{c}\text { Zona } \\
\text { Ham } \\
\text { bat } \\
(\mathbf{m m})\end{array}$ \\
\hline $\begin{array}{l}\text { A1 } \\
\text { B1 }\end{array}$ & 3,88 & 9,70 & 162 & 87,5 & 0 & 5,3 \\
\hline $\begin{array}{l}\text { A1 } \\
\text { B2 }\end{array}$ & 5,38 & 9,30 & 157 & 50 & 0 & 7,7 \\
\hline $\begin{array}{l}\text { A1 } \\
\text { B3 }\end{array}$ & 4,86 & 9,90 & 161 & 60 & 0 & 5,7 \\
\hline $\begin{array}{l}\text { A2 } \\
\text { B1 }\end{array}$ & 1,27 & 9,80 & 148 & 71 & 0 & 7,3 \\
\hline $\begin{array}{l}\text { A2 } \\
\text { B2 }\end{array}$ & 4,25 & 10,10 & 144 & 17 & 0,36 & 5,0 \\
\hline $\begin{array}{l}\text { A2 } \\
\text { B3 }\end{array}$ & 4,33 & 10,20 & 120 & 10 & 0 & 7,0 \\
\hline $\begin{array}{l}\text { A3 } \\
\text { B1 }\end{array}$ & 2,09 & 9,400 & 152 & 66 & 0 & 6,7 \\
\hline $\begin{array}{l}\text { A3 } \\
\text { B2 }\end{array}$ & 4,23 & 9,8 & 144 & 15 & 0,3 & 5,3 \\
\hline $\begin{array}{l}\text { A3 } \\
\text { B3 }\end{array}$ & 5,07 & 11,5 & 150 & 27 & 0,45 & 5,3 \\
\hline
\end{tabular}

Keterangan:

Penambahan Sukrosa (A) dan Gliserin (B)

- Al B1 (7,5 gr 6,5 gr)

- A1 B2 (7,5 gr 8,5 gr)

- A1 B3 (7,5 gr 10,5gr)

- A2 B1 (9,5 gr 6,5 gr)

- A2 B2 (9,5 gr 8,5gr )

- A2 B3 (9,5 gr 10,5 gr)

- A3B1 (11,5 gr 6,5 gr)

- A3 B2 (11,5 gr 8,5 gr)

- A3 B3 $(11,5$ gr $10,5 \mathrm{gr})$

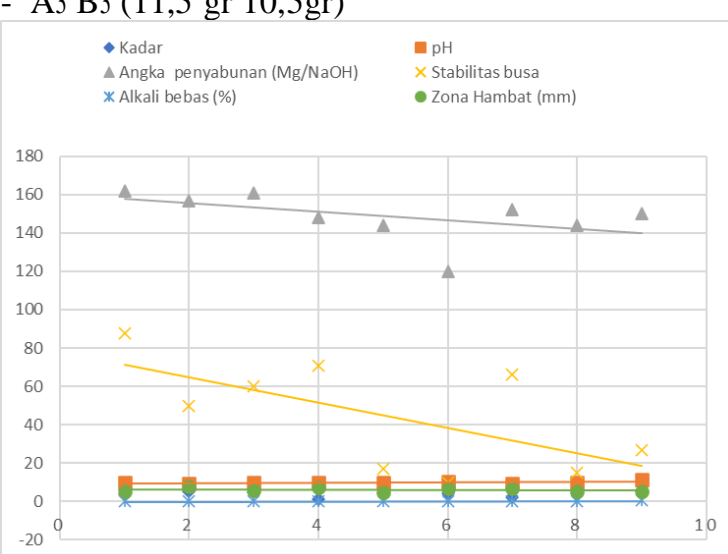

\section{Gambar 1. Trendline Analisa Mutu Sabun Transpran Penambahan Ekstrak Ketepeng}

\subsection{Kadar Air}

Kadar air sabun berdasarkan SNI (Standar Nasional Indonesia) 06-3532-1994 yaitu maksimal $15 \%$. Hasil pengujian kadar air sabun transparan pada berbagai formulasi memenuhi SNI. Pengaruh konsentrasi sukrosa dan gliserin menunjukkan semakin tinggi konsentrasi sukrosa yang digunakan maka semakin tinggi kadar air yang dihasilkan. Hal ini disebabkan kemampuan sukrosa dalam mengikat air. Hal ini sesuai pendapat (Winarno, 1994) yang menyatakan semakin tinggi konsentrasi sukrosa yang digunakan maka semakin banyak air yang terikat oleh gula, maka semakin banyak air dalam sabun.

Hasil pengamatan pada pengaruh gliserin menunjukkan semakin tinggi konsentrasi yang digunakan maka kadar air yang dihasilkan semakin tinggi pula. Hal ini menandakan gliserin mempengaruhi kadar air pada sabun transparan yang dihasilkan karena gliserin merupakan humektan yang bersifat higroskopis sehingga dapat meningkatkan air dalam sabun yang akan mempengaruhi tekstur sabun (Hambali, dkk., 2007). 


\section{$3.2 \mathrm{pH}$}

Purnamawati (2006) menyebutkan sabun sebagai garam alkali yang bersifat basa. Standar pH untuk sabun mandi menurut SNI berkisar antara 9-11. sukrosa merupakan larutan alkali yang dapat meningkatkan $\mathrm{pH}$. Semakin tinggi larutan sukrosa semakin banyak ion hidroksil sehingga akan menurunkan ion $\mathrm{H}+$ dalam sabun. Hal ini yang menyebabkan $\mathrm{pH}$ sabun meningkat (basa) seiring dengan peningkatan sukrosa.

\subsection{Alkali Bebas}

Alkali bebas merupakan alkali yang tidak terikat sebagai senyawa pada saat pembuatan sabun. Kadar alkali bebas dihitung sebagai kadar $\mathrm{NaOH}$. Menurut SNI kelebihan alkali dalam sabun tidak boleh melebihi $0,1 \%$ karena alkali bersifat keras dan dapat menyebabkan iritasi pada kulit (Purnamawati, 2006).

Berdasarkan Tabel 1 diketahui peningkatan konsentrasi sukrosa dan gliserin dapat meningkatkan persentase alkali bebas. Hal ini disebabkan karena sukrosa dan gliserin dapat mengikat air, sehingga air yang digunakan sebagai pelarut tidak mencukupi. Hal ini menyebabkan $\mathrm{NaOH}$ yang ditambahkan pada sabun transparan memiliki kosentrasi yang pekat, sehingga proses saponifikasi berlangsung tidak optimal menyebabkan alkali bebas meningkat.

\subsection{Angka Penyabunan}

Angka penyabunan menunjukkan proses netralisasi antara asam lemak dan basa dalam pembentukan stok sabun. Berdasarkan hasil pengamatan semakin tinggi konsentrasi sukrosa dan gliserin yang digunakan maka semakin rendah angka penyabunan yang dihasilkan. Sukrosa dan gliserin bersifat mengikat air sehingga menyebabkan berkurangnya sediaan air untuk melarutkan basa. Hal ini menyebabkan pelarutan basa $\mathrm{NaOH}$ dalam sediaan sabun kurang maksimal.

Jika angka penyabunan tidak sempurna, dapat menyebabkan persentase alkali bebas meningkat. Dapat dilihat pada gambar 1 penurunan trendline angka penyabunan menyebabkan peningkatan trendline alkali bebas.

\subsection{Stabilitas Busa}

Pengukuran terhadap kestabilan busa pada sampel menunjukkan semakin tinggi konsentrasi sukrosa dan gliserin yang digunakan maka stabilitas busa yang dihasilkan semakin menurun. Menurut Gwi-Taek Jeong, et.al., (2002) pH basa dapat menurunkan stabilitas busa. Menurut Gusviputri, dkk. (2013) jika basa yang digunakan terlalu pekat akan menyebabkan terpecahnya emulsi pada larutan, sehingga fasenya tidak homogen. Hal ini yang menyebabkan stabilitas busa menurun seiring dengan peningkatan sukrosa dan gliserin. Pada gambar 1 dapat dilihat peningkatan trendline $\mathrm{pH}$ seiring dengan penurunan trendline stabilitas busa.

\subsection{Zona Hambat}

Daya hambat adalah kemampuan suatu senyawa untuk menghambat pertumbuhan mikroorganisme tertentu. Semakin besar zona hambat menentukan semakin besar pula kemampuan senyawa tersebut menghambat mikroorganisme. Berdasarkan tabel 1 diketahui peningkatan konsentrasi sukrosa menyebabkan zona hambat mengalami penurunan. Menurut González-Garcinuño et al., (2017) sukrosa dapat mempengaruhi aktivitas pada bakteri gram negatif. Namun secara keseluruhan hasil analisa zona hambat pada 9 formulasi sabun transparan dengan penambahan ekstrak ketepeng memiliki respon zona hambat sedangkuat. Menurut Pan, et.al (2009) diameter zona hambat 0-3 $\mathrm{mm}$ respon hambatan pertumbuhan lemah, sedangkan diameter 3-6 $\mathrm{mm}$ respon sedang, dan > $6 \mathrm{~mm}$ memiliki respon yang kuat.

\subsection{Uji Efektivitas (Metode DeGarmo)}

Metode DeGarmo digunakan untuk menentukan perlakuan terbaik dari formulasi sabun berdasarkan Indeks Efektivitas. Langkah pertama yang dilakukan dalam uji ini adalah menentukan bobot nilai panelis. Panelis yang digunakan dalam penelitian ini adalah panelis terlatih sebanyak 6 orang.

Berdasarkan perhitungan uji De Garmo diketahui perlakuan terbaik yaitu A3B3 (sukrosa 11,5 gram; gliserin 10,5 gram), namun perlakuan tersebut memiliki alkali bebas melebihi standar Nasional Indonesia, sehingga perlakuan terbaik kedua adalah A1B1. Sampel A1B1 (sukrosa 7,5 gram; gliserin 6,5 gram) digunakan sebagai sampel pada tahap kedua. 


\subsection{Uji Organoleptik}

Tabel 7 adalah hasil pengamatan uji organoleptik sabun transparan dengan penambahan ekstrak ketepeng dengan variasi parfum. Berdasarkan uji kesukaan terhadap aroma menunjukkan bahwa nilai rata-rata kesukaan panelis antara 6,08 (agak suka) sampai 6,96 (suka). Skor aroma tertinggi pada sabun dengan penambahan parfum daun jambu dan kenanga. Berdasarkan hasil perhitungan sidik ragam diketahui bahwa terdapat beda nyata antar perlakuan variasi parfum. Angka yang memiliki notasi yang sama menunjukkan tidak berbeda nyata.

Uji kesukaan terhadap busa menunjukkan bahwa nilai rata-rata kesukaan panelis antara 6,84 sampai 6,96 (suka). Berdasarkan hasil perhitungan sidik ragam diketahui bahwa terdapat tidak beda nyata antar perlakuan variasi parfum. Hal ini menunjukkan bahwa variasi parfum tidak mempengaruhi busa pada sabun transparan ektrak ketepeng.

Tabel 2. Uji Organoleptik Sabun Transparan Ekstrak Ketepeng dengan Variasi Parfum

\begin{tabular}{|l|c|c|c|c|}
\hline \multirow{2}{*}{$\begin{array}{l}\text { Jenis } \\
\text { Parfum }\end{array}$} & \multicolumn{4}{|c|}{ Rata-rata } \\
\cline { 2 - 5 } & $\begin{array}{c}\text { Arom } \\
\mathbf{a}\end{array}$ & $\begin{array}{c}\text { Bus } \\
\mathbf{a}\end{array}$ & $\begin{array}{c}\text { Penerimaan } \\
\text { Secara } \\
\text { Keseluruha } \\
\mathbf{n}\end{array}$ & $\begin{array}{c}\text { Rerat } \\
\mathbf{a}\end{array}$ \\
\hline Lemon & $6,28 \mathrm{~b}$ & 6,96 & $6,28 \mathrm{~b}$ & 6,50 \\
\hline $\begin{array}{l}\text { Daun } \\
\text { Jambu }\end{array}$ & $6,96 \mathrm{a}$ & 6,84 & $7,00 \mathrm{a}$ & 6,93 \\
\hline $\begin{array}{l}\text { Kenang } \\
\text { a }\end{array}$ & $6,96 \mathrm{a}$ & 6,92 & $6,52 \mathrm{~b}$ & 6,80 \\
\hline Melati & $6,08 \mathrm{~b}$ & 6,88 & $6,24 \mathrm{~b}$ & 6,40 \\
\hline
\end{tabular}

Uji penerimaan secara keseluruhan merupakan atribut yang paling penting bagi konsumen dalam menentukan sebuah pilihan. Berdasarkan uji kesukaan terhadap penampakan secara keseluruhan menunjukkan bahwa nilai rata-rata kesukaan panelis antara 6,24 (agak suka) sampai 7 (suka). Berdasarkan hasil perhitungan sidik ragam diketahui bahwa terdapat beda nyata antar perlakuan variasi parfum. Angka yang memiliki notasi yang sama menunjukkan tidak berbeda nyata.

Berdasarkan rerata uji organoleptik diketahui bahwa sabun transparan ekstrak daun ketepeng dengan penambahan parfum daun jambu memiliki skor rerata tertinggi. Hal ini dapat dijadikan dasar untuk menentukan perlakuan terbaik.

\subsection{Uji Iritasi}

Penggunaan sabun mandi yang baik pada kulit biasanya tidak menyebabkan iritasi. Uji iritasi kulit dilakukan dengan cara mencuci tangan hingga pergelangan sampai sabun berbusa selama 3 hari berturut-turut. Pemeriksaan ini dilakukan terhadap lima orang panelis yang sama untuk masing-masing sabun. Diamati iritasi yang terjadi dengan memberikan penilaian (-) jika tidak terjadi iritasi, dan (+) jika iritasi ringan, $(++)$ jika iritasi berat. Perubahan yang terjadi berupa kemerahan dan gatal-gatal (Febriyanti, dkk. 2014).

Formulasi yang digunakan untuk uji iritasi adalah A1B1 yang ditambahkan dengan berbagai jenis parfum. Uji iritasi ini dilakukan terhadap 12 orang panelis.

Tabel 7. Hasil Uji Iritasi Sabun Transparan Ekstrak Daun Ketepeng dengan Berbagai Konsentrasi dan Variasi Parfum

\begin{tabular}{|l|c|c|c|}
\hline \multicolumn{1}{|c|}{ Sampel } & Hari 1 & Hari 2 & Hari 3 \\
\hline $\begin{array}{l}\text { Sabun } \\
\text { transparan } \\
\text { lemon }\end{array}$ & - & - & - \\
\hline $\begin{array}{l}\text { Sabun } \\
\text { transparan daun } \\
\text { jambu }\end{array}$ & - & - & - \\
\hline $\begin{array}{l}\text { Sabun } \\
\text { transparan } \\
\text { kenanga }\end{array}$ & - & - & - \\
\hline $\begin{array}{l}\text { Sabun } \\
\text { transparan } \\
\text { melati }\end{array}$ & - & - & - \\
\hline
\end{tabular}

Hasil uji iritasi pada sabun transparan menunjukan bahwa sabun tidak menyebabkan iritasi, ditandai dengan tidak menunjukan gejala timbulnya warna merah dan kulit tidak terasa gatal setelah pengujian yang dilakukan selama 3 hari berturut-turut. Hal ini diperkuat dengan data alkali bebas sabun konsentrasi A1B1 (sukrosa 7,5 g : gliserin 6,5 g) menunjukkan nilai $0 \%$.

\section{KESIMPULAN}

Berdasarkan hasil penelitian diketahui bahwa formulasi terbaik sabun transparan ekstrak daun ketepeng adalah penambahan 
sukrosa 7,5 gram dan gliserin 6,5 gram dengan variasi parfum daun jambu.

\section{DAFTAR PUSTAKA}

De Garmo, E.P. W.G. Sullivan dan Canada, J.R. (1984). Engineering Economy The $7^{\text {th }}$ Edition Macamillan Publishing Comp. New York.

Febriyenti, Sari L.I., Nofita R. (2014). Formulasi Sabun Transparan Minyak Ylang-Ylang dan Uji Efektivitas terhadap Bakteri Penyebab Jerawat. Jurnal Sains Farmasi \& Klinis (ISSN: 2407-7062). Vol. 01 No. 01.

González-Garcinuño (2017). Efect of bacteria type and sucrose concentration on levan yield and its molecular weight. Microb Cell Fact (2017) 16:91.

Gusviputri, A., Meliana N. P. S, Aylianawati, Indraswati. (2013). Pembuatan Sabun Dengan Lidah Buaya (Aloe Vera) Sebagai Antiseptik Alami. WIDYA TEKNIK Vol. 12, No. 1, 2013 (11-21).

Gwi-Taek Jeong, Hwa-Won Ryu, Yung-Il Joe, Don-Hee Park, and Tanner, R.D. (2002). Effect of $\mathrm{pH}$ on the Foam Fractionation of Seed Proteins. Theories and Applications of Chem. Eng., 2002, Vol. 8, No. 2.

Hambali, E. A. Suryani dan M. Rival. (2005). Membuat Sabun Transparan Penebar Plus, Jakarta.

Idrus, M.A., Harismah, K., Sriyanto A. (2013). Pemanfaatan kemangi (Ocimum sanctum) sebagai subtitusi aroma pada pembuatan sabun herbal antioksidan. Simposium Nasional Teknologi Terapan (SNTT) 2013.

Juliansyah dan Paotonan. (2017). Uji Daya Hambat Sediaan Sabun Transparan

Ekstrak Jarak Pagar (Jatropha curcas) Terhadap Pertumbuhan Bakteri Uji Propionibacterium acnes. Jurnal Mandala Pharmacon Indonesia, Vol 3.No.2.

Kusnardi., Kumala, S., dan Enif, E. (2007). Efek Imunomodulator Ekstrak Daun Ketepeng Cina (Cassia alata) Terhadap Aktivitas dan Kapasitas Fagositosis Makrofag. Jurnal Makara Kesehatan, Vol 11. No. 2

Muchtaridi, (2008). Penelitian Pengembangan Minyak Atsiri Sebagai Aromaterapi dan Potensinya Sebagai Produk Sediaan
Farmasi. Fakultas Farmasi Universitas Padjadjaran. Bandung.

Mumpuni, A. S., dan Sasongko, H. 2017. Mutu sabun transparan ekstrak etanol herba pegagan (Centella asiatica L.) setelah penambahan sukrosa. Pharmaciana Vol.7, No.1, Mei 2017, Hal. 71-78

Pan, X., Chen, F., Wu, T., Tang, H., and Zhao, Z. (2009). The acid, Bile Tolerance and Antimicrobial property of Lactobacillus acidophilus NIT. J. Food Control 20 : 598-602.

Priani, E, S., Lukmayani, Y., (2010). Pembuatan Sabun Transparan Berbahan Dasar Minyak Jelantah Serta Hasil Uji iritasinya Pada Kelinci. Prosiding Snapp, Universitas Islam Bandung, Bandung.

Purnamawati, D. (2006). Kajian Pengaruh Kosentrasi Sukrosa dan Asam Sitrat Terhadap Mutu Sabun Transparan. Institut Pertanian Bogor.

Setyaningsih, D. Apriyantono, A dan Sari, M, P. (2010). Analisis Sensori untuk Industri Pangan dan Argo. Bogor: IPB Press.

Setyoningrum, Maharani, E.N., (2010). OptimasinFormula Sabun Transparan Dengan Fase Minyak Virgin Coconut Oil dan Surfaktan Cocoamidopropyl Betaine: Aplikasi Desain Faktorial. Universitas Sanata Dharma, Yogyakarta.

Silvia (2008). Formulasi sabun transparan dari minyak nilam (patchouli oil) dan VCO serta uji aktifitasnya terhadap bakteri penyebab jerawat. [Skripsi]. Jurusan farmasi Universitas Andalas. Padang.

Sudarmadji, S Suhardi dan Haryono, B., (1997). Analisa Bahan Makanan dan Pertanian. Liberty, Yogyakarta.

Sukeksi, L., Sidabutar, A.J., Sitorus, C. (2017). Pembuatan Sabun Dengan Menggunakan Kulit Buah Kapuk (Ceiba petandra) Sebagai Sumber Alkali. Jurnal Teknik Kimia USU, Vol. 6, No. 3. 